\title{
O EDITOR DA FBV E A DESINTRUSÃO DA TERRA INDÍGENA RAPOSA SERRA DO SOL: ENUNCIADOS, ENUNCIAÇÕES E CONTEXTO
}

\author{
THE EDITOR OF FBV AND THE REMOVAL OF THE TERRA INDIGENA \\ RAPOSA SERRA DO SOL: STATEMENT, ENUNCIATIONS, AND CONTEXT
}

\author{
EL EDITOR DE LA FBV Y LA DESINTRUSIÓN DE LA TIERRA INDÍGENA \\ RAPOSA SERRA DO SOL: ENUNCIADOS, ENUNCIACIONES Y CONTEXTO
}

\author{
Wenya Alecrim ${ }^{1}$ \\ Jornalista, e mestranda em Comunicação pela Universidade Paulista \\ wenyaalecrim@hotmail.com \\ Dr ${ }^{\mathrm{a}}$ Bárbara Heller ${ }^{2}$ \\ Docente no mestrado em Comunicação da Universidade Paulista \\ b.heller@terra.com.br
}

\begin{abstract}
Resumo
$\mathrm{O}$ artigo concentra-se na análise de discurso de 12 artigos publicados pelo jornal Folha de Boa Vista, durante o processo final de retirada de não-índios da terra indígena Raposa Serra do Sol (RR). Seu autor é editor-chefe do jornal, de descendência indígena, e imprimiu em seus textos posicionamento quanto ao assunto, apesar de estar contra a linha editorial do veículo. Em meio a conflitos em maio de 2009, foram retirados centenas de pequenos agricultores e grandes empresários exportadores de arroz. Por meio do referencial teórico da análise do discurso apoiada em Mikhail Bakhtin, Dominique Maingueneau e Beth Brait, buscamos entender o contexto no qual foram escritos os textos e ainda que significados e representações produziram.
\end{abstract}

Palavras - chave: análise do discurso, índios, jornalismo.

Esta obra está licenciada sob uma Licença Creative Commons 


\begin{abstract}
The present paper focuses on the discourse analysis of 12 articles published by the Folha de Boa Vista newspaper, during the final process of removal, in 2009, of non-indigenous people from the Terra Indigena Raposa Serra do Sol (RR-Brazil) - an indigenous reservation in the state of Roraima, north of Brazil. The author of the articles is the publication's editor-in-chief, of indigenous descent, who imprinted on his writings his positioning on the subject, despite its going against the vehicle's editorial line. Amid conflicts, hundreds of small farmers and large rice exporting companies were expelled from the area in may 2009. Through the discourse analysis' theoretical referential supported in Mikhail Bakhtin, Dominique Maingueneau and Beth Brait, we seek to understand the context within which the pieces were written, as well as what meanings and representations they produced.
\end{abstract}

Key words: discourse analysis, indigenous peoples, journalism.

\title{
Resumen
}

El artículo se concentra en el análisis de discurso de 12 artíclos publicados pelo periódico Folha de Boa Vista, durante el proceso final de retirada de los no-indígenas de la tierra indígena Raposa Serra do Sol (RR-Brasil). Su autor es editor-jefe Del periódico, de descendencia indígena, e há imprimido su posicionamento al tema em los textos, a pesar de estar em contra de su linea editorial. En medio a conflictos ocurridos e mayo del 2009, han sido sacados centenares de pequeños agricultores y grandes empresarios exportadores de arroz. Por medio del referencial teórico de análisis del discurso apoyada en Mikhail Bakhtin, Dominique Maingueneau y Beth Brait, buscamos comprender el contexto en el cual fueron escritos los textos y aún los significados y también las representaciones que han producido.

Palabras clave: análisis de discurso, indígenas, periodismo.

\section{INTRODUÇÃO}

No Estado de Roraima, o que se viu, nos últimos 30 anos, foi uma luta entre índios e brancos. A disputa pela Terra Indígena Raposa Serra do Sol motivou a comunidade indígena local a se organizar para conseguir de volta, uma terra habitada por eles há anos, com direito de posse e usufruto do território. Diferentemente do que muitos pensavam, por meio de estratégias políticas, os índios foram vitoriosos nesta batalha (segundo eles mesmos consideram) contra grandes produtores de arroz.

No dia 19 de março de 2009 o Supremo Tribunal Federal confirmou a homologação contínua da Terra Indígena Raposa Serra do Sol (ou seja, deu posse aos índios não só as terras habitadas em caráter permanente, mas também as utilizadas para atividades produtivas, necessárias à sua reprodução física e cultural, segundo usos, costumes e tradições), 
determinando a retirada imediata dos não-indígenas da região. Foram oito votos contra um. A decisão durou dois dias. Em Boa Vista (Roraima) as atenções estavam voltadas para as televisões que transmitiam ao vivo a votação. O prazo para todos desintrusados saírem espontaneamente da reserva expirou no dia 30 de abril do mesmo ano. Pelas ruas, moradores especulavam o que se tornaria o Estado de Roraima, uma vez que a economia era movimentada pela exportação de arroz. Muitas famílias que trabalhavam nas fazendas de arroz ainda temiam não encontrar emprego na capital. Os indígenas, por sua vez, começaram a planejar o que fariam com a terra e traçar projetos de desenvolvimento da região.

Um dos poucos autores a utilizar o termo "desintrusão", ao se referir à retirada dos não-índios que ocupavam a T.I, foi o antropólogo Paulo Santilli (2001, p. 93). Apesar de no Estado a população utilizá-lo corriqueiramente, para alguns acadêmicos longe da região Norte ele é estranho.

O jornal $F B V$ (daqui por diante FBV) foi inaugurado em 1983. Com o slogan "Um jornal necessário", a FBV é o jornal mais antigo do estado ainda em circulação. Talvez por sempre ter sido identificado com o poder político local, é visto pelos leitores roraimenses como o jornal de maior credibilidade, qualidade reforçada tanto pelos anos de atuação, quanto pela linha editorial que desenvolveu.

Em função deste histórico político e ideológico, mas pautada na linha investigativa, sua característica mais visível, a FBV, foi um dos veículos do Estado que mais deu destaque à desintrusão. Para se ter uma ideia, basta dizer que apenas em 2009, o tema apareceu cerca de 360 vezes distribuídos em 86 capas, 170 matérias, 36 artigos, entre outras publicações como notas na coluna social, respostas do público no espaço do leitor, cartoon e anúncios.

Para este artigo separamos todos os 12 artigos publicados pelo editor-chefe do jornal $F B V$, Jessé Souza em 2009 sobre o tema. Analisamos os textos por meio da teoria da análise do discurso abordando alguns conceitos de linha francesa, que teve início por volta de 1960, a partir das teorias do russo Mikhail Bakhtin, formuladas nas primeiras décadas do século XX. Neste momento o que se pretende é pontuar a análise do discurso segundo a visão de autores e pensadores que ao longo dos anos estudam seus significados.

Para Dominique Maingueneau estudioso da análise de discurso de linha francesa, é notório observar a proliferação do termo “discurso" nas ciências da linguagem.

Emprega-se tanto no singular ("o domínio do discurso", a "análise do discurso", "cada discurso é único" etc.) quanto no plural, ("os discursos se 
inscrevem em contextos" etc.), conforme ele se refira à atividade verbal em geral ou a cada evento de fala (MAINGUENEAU 2001, p.49).

Cada enunciado é portador de um sentido estável, que lhe foi conferido pelo locutor, destaca Mainguenau. O sentido de alguma forma está inscrito no enunciado e é decifrado por um receptor que dispõe do mesmo código e que fala a mesma língua do enunciador. Por enunciado entende-se o produto da enunciação, isto é, o ato de produzir o dito. Ou seja, o dizer origina a enunciação, e o dito, o enunciado. Os enunciados se comportam como produto de uma enunciação que implica uma cena. Além disso, toda fala procede de um enunciador encarnado, mesmo quando o texto é escrito. O enunciado- se opõe à enunciação da mesma forma que produto se opõe ao ato de produzir, nesta perspectiva, o enunciado é a marca verbal do acontecimento que é a enunciação. (MAINGUENEAU, 2001: 21, 96).

Bakhtin (2009, p.109), pondera que toda enunciação, mesmo na forma imobilizada da escrita, é uma resposta a alguma coisa e é construída como tal. Ou seja, o sentido da palavra é totalmente determinado por seu contexto. É importante dizer ainda que a palavra pode ser apenas uma, mas construir várias significações como também vários contextos. Beth Brait (2010, p. 63) explica o pensamento de Bakhtin da seguinte forma: uma única frase ganha diferentes sentidos em diferentes realizações enunciativas. Ou melhor, uma determinada frase pode ganhar um sentido dependendo do "local" em que é empregada.

A autora dedica um artigo para discutir sobre os termos enunciação e enunciado de Bakhtin. Uma de suas considerações aponta que conforme o pensamento bakhtiniano enunciado é tido como o produto de um processo, isto é a enunciação é o processo que produz e nele deixa marcas da subjetividade. E ainda

Enunciado implica muito mais do que aquilo que está incluído dentro dos fatores estritamente lingüísticos, o que vale dizer, solicita um olhar para outros elementos que o constituem [...] enunciado como unidade da comunicação discursiva, diferenciando-a das unidades da língua. (BRAIT, 2010, p. 69 e 70).

Os conceitos de Bakhtin e Maingueneau nos permitem pensar que apenas conhecer determinada língua não será suficiente para entender e interpretar um enunciado. Na verdade para isso será necessário ter ciência do contexto em que está situada.

Para Bakhtin (2009, p. 96), para quem a "língua não reside na conformidade à norma da forma utilizada, mas na nova significação que essa forma adquire no contexto". Em outras palavras, a língua permanecerá idêntica, o que vai mudar, na verdade, é o contexto e por isso 
ganhará nova significação. É neste sentido que pretendemos analisar nosso corpus, a fim de ampliar as discussões sobre as interferências e significados que a mídia produz em determinada comunidade.

Segundo Beth Brait (2007), é necessário olhar para fora do texto, ou como sugere Michael Foucault, enfrentar a "massa de traços" verbais e extraverbais que povoa o texto e aponta para fora dele, vinculando, social e historicamente, sujeito, vida e linguagem:

[...] embora o homem seja no mundo o único ser que fala, não constitui de modo algum ciência humana o conhecer as mutações fonéticas, o parentesco das línguas, a lei das derivações semânticas; em contrapartida, poder-se-á falar de ciência humana desde que se procure definir a maneira como os indivíduos ou os grupos concebem as palavras, utilizam a sua forma e o seu sentido, compõem discursos reais, neles mostram e ocultam o que pensam, dizem, sem que talvez tenham consciência disso,mais ou menos do que pretendem dizer, deixam, em todo caso, desses pensamentos, uma massa de traços que é necessário decifrar e restituir tanto quanto é possível à sua vivacidade representativa [...]. (FOUCAULT apud BRAIT, 1997, p.170)

Em outro texto Foucault salienta que o que interessa no discurso, é o fato de que alguém disse algo em algum dado momento.

[...] trata-se de considerar o discurso como uma série de acontecimentos, de estabelecer e descrever as relações que esses acontecimentos mantém com outros [...] Em um certo momento não somos nada além do que aquilo que foi dito há séculos, meses, semanas. (FOUCAULT apud GREGOLIN, 2007 p.12).

Os parágrafos acima não tiveram a pretensão de expor detalhadamente os conceitos da AD francesa, mas apenas de indicar os que serão utilizados para análise dos textos da $F B V$.

\section{JESSÉ SOUZA}

Jessé Souza, o editor-chefe da $F B V$, nasceu no dia 1 de fevereiro de 1970, em Boa Vista, filho de um garimpeiro com uma indígena de origem Wapixana e Macuxi. Alguns dos seus familiares ainda moram em áreas indígenas. Segundo o próprio editor do jornal, desde a infância quis ser jornalista e pelas escolas por onde passou, produziu jornaizinhos mimeografados e/ou datilografados. Ainda jovem Jessé trabalhava na Assessoria de Comunicação da Diocese de Roraima, que deu apoio à causa indígena. Os textos publicados nos informativos da Igreja aturam como porta de entrada para a imprensa diária. Em 1996 Jessé começou a trabalhar na $F B V(\mathrm{FBV})$, para onde já escrevia esporadicamente artigos, 
alguns deles em defesa da causa indígena. Segundo ele foi preciso enfrentar uma grande pressão dos leitores conservadores do jornal e da sociedade roraimense. Por também tratar de outros assuntos polêmicos ele conseguiu falar da questão indígena abertamente, sem ganhar o rótulo de "jornalista dos índios". Após ser contratado como repórter, um ano depois, tornou-se editor de cidade, cargo que não existia e que foi criado como uma preparação para que assumisse a editoria-geral, o que ocorreria cinco anos mais tarde.

No final do primeiro semestre de 2009, período de conflitos da desisntrusão, Jessé Souza saiu da editoria geral, por questões de saúde, colaborando com o jornal apenas aos finais de semana. Em maio de 2010 retornou à edição diária, numa experiência de "editoria compartilhada" com a jornalista Lóide Gomes.

Ao longo de meu trabalho como repórter e depois editor, sempre escrevi artigos de opinião com fundo crítico, especialmente na questão indígena, me colocando como o único jornalista em Roraima a se posicionar favoravelmente em favor da Terra Indígena Raposa Serra do Sol. (Jessé Souza, entrevista via e-mail, 2010).

Tabulamos o material publicado pela $F B V$ em 2009. Os 12 artigos do editor-geral que trataram sobre a desintrusão, estiveram assim, distribuídos: janeiro e fevereiro: 01 em cada mês; abril: 03; maio: 02; setembro e outubro: 01 em cada mês e dezembro: 03. Nos meses em que não houve publicação, o editor estava afastado do jornal por motivos de saúde. Para efeito de clareza numerei os artigos de 01 a 12, de acordo com a ordem cronológica que foram publicados:

\begin{tabular}{|c|c|c|}
\hline 01 & $30 / 01 / 2009$ & "Eles" e o fim do discurso \\
\hline 02 & $11 / 02 / 2009$ & Sapo barbudo vira príncipe \\
\hline 03 & $01 / 04 / 2009$ & "Terra de Ninguém" \\
\hline 04 & $02 / 04 / 2009$ & Fim de um ciclo \\
\hline 05 & $03 / 04 / 2009$ & Solidariedade?! \\
\hline 06 & $01 / 05 / 2009$ & Cai mais um entulho \\
\hline 07 & $05 / 05 / 2009$ & Mais que espernear \\
\hline 08 & $15 / 09 / 2009$ & Hora de trabalhar \\
\hline 09 & $21 / 10 / 2009$ & Pluralidade nos 26 anos \\
\hline 10 & $09 / 12 / 2009$ & Vale-Preguiça e Pró-moleza \\
\hline 11 & $08 / 12 / 2009$ & Nem pepino para o povo \\
\hline 12 & $17 / 12 / 2009$ & A faca e o queijo \\
\hline
\end{tabular}


Quadro 1 - Títulos dos artigos publicados na FBV por Jessé Souza

Fonte: Construído pela autora

Para Melo (2003, p.121), o artigo de jornal possui duas significações. Uma diz respeito a toda matéria publicada em jornais ou revistas. A outra é peculiar às instituições jornalísticas. Trata-se de uma matéria jornalística ou não, na qual alguém desenvolve uma ideia e apresenta sua opinião, publicada normalmente nas páginas editoriais ou em suplementos especializados. Em geral estes artigos tratam de um fato ou ideia da atualidade, momento histórico vivido, inter-relacionando com outras notícias do jornal. A argumentação utilizada no artigo baseia-se no próprio conhecimento e sensibilidade do articulista

Da maneira geral observamos nos artigos um enunciador que transmitiu aos seus textos características essenciais do ethos, isto é, a imagem que o autor pretende dar de si mesmo, pelo modo e tom de voz expressos. Para Maingueneau (2001), o orador enuncia uma informação e ao mesmo tempo diz: eu sou isto, eu não sou aquilo.

A qualidade do ethos remete, com efeito, à imagem desse fiador que, por meio de sua fala, confere a si próprio uma identidade compatível, com o mundo que ele deverá construir em seu enunciado. (MAINGUENEAU, p.99, 2001).

Jessé Souza, por ser editor do jornal, confere uma opinião mais autorizada do que a de um cidadão comum. Mas isso não justifica as palavras muitas vezes agressivas e pejorativas de que se utiliza para defender suas opiniões a favor dos índios; apenas permite ao leitor desenhar uma representação do corpo do enunciador que, apesar de nunca declarar sua origem étnica, acaba por revelar sua identificação com este grupo social, seja por ideologia política, seja por descendência familiar.

Mas esse ethos não diz respeito apenas, como na retórica antiga, à eloquiência judiciária ou aos enunciados orais: é válido para qualquer discurso, mesmo para o escrito. Com efeito, o texto escrito possui, mesmo quando denega, um tom que dá autoridade ao que é dito [...]. A leitura faz então emergir uma instância subjetiva que desempenha o papel de fiador do que é dito. (MAINGUENEAU, p.98, 2001, grifo nosso).

Com uma linguagem simples, aproximando-se algumas vezes do coloquial, reconhece- se nos artigos de Jessé Souza um tom crítico, muitas vezes agressivo, como dito 
anteriormente. Na maioria deles os políticos são alvos de seus comentários. No artigo 01, publicado em 30 de janeiro de 2009, o editor produz um efeito de sentido nas palavras e adjetiva-os de "incompetentes".

A oficialização do repasse das terras da União para Roraima tem um significado singular: a queda do último discurso dos políticos locais que sempre utilizaram esse problema para justificar o não desenvolvimento de Roraima e a incompetência deles para tratar dos assuntos da coletividade.

No passado, culparam a falta de estrada; então a BR-174 está aí, ligando Roraima ao Amazonas e à Venezuela. Depois diziam que era a falta de energia; a energia de Guri é realidade, e só não chegou ao interior do Estado porque "eles" roubaram o dinheiro das obras.

Diziam também que a culpa era dos índios. Agora sabemos o que é terra dos índios e o que é terra dos "brancos". Culparam a falta de repasse das terras para Roraima; e finalmente Lula da Silva concretizou a transferência. E agora, José, que monstro vão criar?

[...] Como os índios não dão lucro para "eles" e a mineração em terras indígenas terá que ser feita por multinacionais que tenham estrutura e condições de furar a terra com o menor impacto possível, então defendem o arroz como "ouro branco" - que não é para o Estado; pode ser para o bolso deles, menos para o povo de Roraima. [...]. (FBV, 30/01/2009, 2009; negrito e itálico meus).

O presidente Luiz Inácio Lula da Silva também não foi poupado das críticas do editor que, no artigo 02 de 11 de fevereiro, usou a expressão "sapo barbudo", já conhecida, para referir-se a ele em seu texto;

[...] Agora, com a transferência das terras da União para o Estado de Roraima, Lula está sendo tratado como herói, com os outrora inimigos disputando fotos, querendo ser o "pai da criança" ou só mesmo querendo aparecer ao lado do antes "sapo barbudo" [...]. (FBV, 11/02/2009; grifo nosso)

Em abril, mês que antecedeu a desintrusão foi, um dos períodos, em que houve maior publicação de artigos (assim como em dezembro): três. Isso significa a quase totalidade das produções do articulista que, não custa lembrar, nesta época escrevia apenas aos finais de semana. No artigo 03, do dia primeiro, Jessé Souza mais uma vez é agressivo;

[...] Quem seria o político maluco que iria pedir regularização fundiária? Quem iria se indispor com a elite agrária, política e econômica local? Quem acreditava que índios miseráveis e xucros um dia iriam lutar por suas terras no Supremo Tribunal Federal [...]. (FBV, 01/04/2010).

Ao adjetivar o político de "maluco", o editor convence o leitor a assumir seu ponto de vista, uma vez que as ações descritas como insanas têm alto valor positivo para os que 
concordam que o Brasil ainda sofre de grandes injustiças sócio-econômicas: pedir a regularização fundiária, se indispor com a elite agrária, apoiar os índios miseráveis e xucros. Por meio deste enunciado, portanto, o editor confere a si próprio uma identidade contestatória, conquistando a adesão dos leitores que se identificam ideologicamente com esta posição.

No dia seguinte, no artigo 04, o editor volta a falar do presidente Lula, que antes da homologação da transferência de terras da União para o Estado, feitas no início de 2009, era "demonizado" e "hoje endeusado". No mesmo texto são usadas expressões como "política do gogó" e "maus políticos", para falar das promessas de palanques dos políticos do estado, que garantiam intervir junto à União para a transferência de terras.

[...] Reforçou, ainda, o fim dessa sentença predatória a regularização fundiária levada a cabo pelo Governo Lula - antes demonizado pelos políticos locais, hoje endeusado pelas mesmas vozes [...]. (FBV, 02/04/2010).

Ou seja, a transferência de terras pôs um ponto final ao pensamento de que em Roraima a terra era de ninguém. Os mesmos políticos do Estado que falavam mal do presidente pela promessa do repasse de terras, passaram a adorá-lo após o feito.

No artigo 05, publicado no dia 03 de abril, Jessé Souza fez duras críticas à possibilidade da visita do deputado federal Aldo Rebelo (PC do B-SP) ao Estado, em solidariedade aos políticos locais depois da decisão final de desintrusão. Em alguns trechos o editor ainda critica o deputado do Estado de São Paulo, que segundo ele, não sabe nem cuidar da despoluição e preservação do Rio Tietê, o que dirá de causas indígenas.

[...] Rebelo e Aurélio (ministro Marco Aurélio STF) se merecem. Assim como São Paulo merece o Tietê...incompetência de lidar sequer com o meio ambiente e com índios remanescentes...o deputado Rebelo faria um bem se fosse cuidar do seu estado [...]. (FBV, 03/04/2010).

As críticas aos políticos ficaram praticamente ausentes no artigo 06, de 01 de maio. Porém voltaram a aparecer no artigo 07, dia 05 do mesmo mês. Por diversas vezes o autor chamou a classe de "espertos", "espertalhões", para dizer que, com artimanhas próprias, conseguiam deixar a sociedade sob seu controle. No contexto em que foram empregadas as palavras "espertos", "espertalhões", a intenção do editor não foi de elogiar os políticos, pelo contrário. Na verdade existiu uma carga negativa sobre as palavras, dando a entender que os políticos estavam “passando a população para trás”, levando vantagens. 
Nos meses de junho, julho e agosto, Jessé esteve afastado do jornal por problemas de saúde, como dito anteriormente. Neste período, entretanto, publicou apenas reportagens especiais. Ele tornou a falar sobre a desintrusão em 15 de setembro. $\mathrm{O}$ editor recorre a termos usados por ele anteriormente, como "política de gogó” e "política do agronegócio que só enriqueceu aos grandes produtores para criticar mais uma vez a classe.

Em dezembro foram publicados 03 artigos. No dia 08, o artigo diz respeito à exposição agropecuária do Estado, que segundo o autor, rendeu apenas prejuízos para quem decidiu expor produtos e máquinas. "Evidente que os políticos já têm o discurso na ponta da língua: a culpa é dos índios".

No artigo do dia seguinte o editor diz que a política do agronegócio "é discurso de tolo, ou espertalhão (leia-se politicos) na mente de roraimense besta”. Mais uma vez o adjetivo "espertalhão" se repetiu no texto do editor, também com sentido negativo. E acrescenta mais um ataque, pois de acordo com ele a única coisa que o estado tem é "tecnologia para corrupção". Ainda no mesmo artigo, Jessé ironiza alguns programas do governo estadual e desqualifica benefícios sociais do Estado renomeando-os de "ValePreguiça" e "Pró-moleza", e destaca que os "políticos sentem até tontura de pensar no fim destes esquemas de assistencialismo”. Desde 2008 o governo do Estado doa vales aos pequenos produtores, conhecidos como Pró-Custeio, no valor de duas parcelas de $\mathrm{R} \$ 250,00$ em compras e Vale Solidário, com doze parcelas de $\mathrm{R} \$ 60,00$, entregues mensalmente a agricultores e colonos da zona rural, pelos órgãos do governo. No texto do editor Vale Solidário, tornou-se "Vale Preguiça", ou seja, uma forma de manter a pagar a preguiça. O programa Pró-Custeio, por sua vez, tornou-se "Pró-moleza", uma crítica a facilidade do pequeno agricultor em conseguir recursos financeiros.

No artigo 12, publicado em 17 dezembro, Jessé não poupou criticas ao governador José de Anchieta Júnior, que recebeu a notícia de absolvição de um processo de cassação que investigava a compra de votos pelo Tribunal Superior Eleitoral. "Anchieta agora governa com a faca e o queijo nas mãos ou 'acelera, como diz o institucional'”, referindo-se à campanha do governo cujo slogan, "Acelera, Roraima", deve ter se inspirado em "Acelera, Ayrton", exaustivamente repetido nas narrações da Fórmula-1, por Galvão Bueno e que, em 1997, transformou-se em “Acelera, Brasil”, utilizado pelo Instituto Ayrton Senna.

Durante a análise destes textos, percebemos que dos 12 artigos publicados pelo editor sobre desintrusão, apenas dois não tiveram como sub-tema a política. Além disso, ficou claro 
durante a leitura que o editor, enquanto cidadão/jornalista acredita que os políticos locais olham para os índios apenas quando lhes é conveniente. Tentam enganar a população de índios e não-índios todo o tempo, como visto nos textos que apresentaram as expressões “espertalhões" e "incompetentes".

\section{E DÁ-LHE “ASPAS"}

Conforme Maingueneau existem formas para o enunciador indicar que não é o responsável por um enunciado. Para isso ele se utiliza do que o autor chama de "modalização em discurso". Ou seja, basta o enunciador indicar que está se apoiando em outro discurso. Expressões como "segundo", "parece", permitem ao enunciador comentar sua própria fala. Isso também pode ser observado com o uso de parênteses, aspas ou fonte em itálico. Colocando as aspas no início e no final do enunciado citado, o enunciador indica estar fazendo menção, desse enunciado, mesmo que este seja de sua propriedade, dito em outra situação. Ao comentar assim sua própria fala, o enunciador produz uma espécie de enlaçamento da enunciação, situação observada em todos os artigos do editor-geral da $F B V$, restando ao leitor compreender o valor das aspas (MAINGUENEAU, 2001, p. 139,159,160).

Em um dos primeiros artigos publicados, Jessé Souza se utiliza das aspas para chamar a classe política de "Eles" grafado com as aspas. A expressão foi usada quatro vezes no mesmo texto. No entanto, o "Eles" assume vários papéis. Em determinados momentos, de acordo com a publicação, o "Eles" refere-se aos produtores de arroz, mais conhecidos no estado como arrozeiros, e em outros, aos políticos. Apoiada em Maingueneau, para descobrir a razão do emprego das aspas e interpretá-las, o leitor deve levar em consideração o contexto.

Os exemplos não param por aí. Em outro artigo o autor volta a utilizar o mesmo "Eles", grafado entre aspas, fazendo menção não só ao o que foi dito por ele, como também por outros enunciadores.

[...] Como verba federal chegava a rodo para Roraima e todos (leia-se "eles") estavam felizes com essa realidade cômoda, foram empurrando tudo com a barriga. "Ah, lá em Brasília a gente ganha nos gabinetes e, se precisar, na Justiça", esnobavam. Para que o roraimense manso e acolhedor não percebesse que "eles", os políticos e seus grupos, estavam sentados em trono de ouro, criaram monstros para desviar a atenção e disfarçar a sanha. ( $F B V$, 01/04/2010, grifo nosso).

Observamos nestes trechos acima, elementos do que Bakhtin chamou de discurso monológico, pois o editor concentrou em si mesmo todo o processo de criação. Apesar de 
dialogar com si próprio, é o único centro irradiador da consciência das vozes, imagens e pontos de vista dos textos, em geral deu a última palavra. "Fecha em seu modelo o mundo representado e os homens representados. Para Bakhtin no universo monológico as personagens não têm mais nada a dizer, já disseram tudo e o autor, de sua posição distanciada já disse tudo por elas e por si" (IN: BRAIT, 2010, p.192). Ao voltar a utilizar o mesmo "Eles", escrito em outro artigo, o autor permitiu a presença de outros textos dentro de um texto, isto é, Jessé construiu um texto dialógico ou intertextual, mas apesar disso monológico. Isso ocorreu, porque ele foi inspirado por textos anteriores, de sua própria autoria. Há vozes, mas a do próprio Jessé de forma "centrípeta”, isto é, quando “deseja imporse como centro de sentido, buscando reduzir o plurívoco ao unívoco (FIORIN, 2008, p. 82).

Para que as aspas sejam decifradas adequadamente, é necessária uma convivência mínima entre enunciador e leitor. Quer dizer, as partes envolvidas devem conhecer previamente do que se trata (MAINGUENEAU, 2001, p. 163), como na expressão "Control C/Control $V$ ", utilizada pelo editor para se referir ao ministro Marco Aurélio que apenas “copiou e colou” o discurso nacionalista acerca da desintrusão para defender seu voto.

Fez "Control C/Control V" de opiniões publicadas em jornais paulistas e trechos de comissões do Senado e da Câmara (que nunca se preocuparam em contratar um antropólogo) enviadas insistentemente para Roraima, como Portugal fazia com o Brasil colônia. ( $F B V$, 03/04/2009).

Desta forma, entende-se que o editor prevê um público leitor familiarizado com a produção de textos por meio de softwares como o "Word".

Segundo Bakhtin (2009, p. 157), aquele que apreende a enunciação de outrem não é um ser mudo, privado de palavra, mas, ao contrário, um ser cheio de palavras interiores. É neste sentido que se efetua a apreensão da enunciação de outrem, compreensão e apreciação, conforme observamos. Para Bakhtin o essencial da tarefa de descodificação não consiste em reconhecer a forma utilizada, mas compreendê-la num contexto concreto preciso, compreender sua significação em uma enunciação particular. Ou seja, o leitor do jornal, pode não entender de fato o que é "Control C, Control $V$ ", mas entender por meio do enunciado que se trata de copiar e colar algo.

Além das aspas podemos perceber o emprego de parênteses nas construções dos artigos para comentar a própria fala, induzindo o leitor a ter a mesma compreensão do texto que ele. Conforme Maingueneau o discurso é orientado, não somente porque é concebido em função de uma perspectiva assumida pelo locutor, mas também por que se desenvolve no 
tempo, de maneira linear. O discurso se constrói, com efeito, em função de uma finalidade, devendo, supostamente, dirigir-se para algum lugar (MAINGUENEAU, 2001, p. 52).

No artigo 03 observamos:

[...] Caso precisasse, os órgãos federais e estaduais, loteados pelos caciques da política (que também fizeram o mesmo loteamento na política), davam apoio não apenas para legitimar a posse como também para ampliar o tamanho dessas propriedades muitas vezes mantidas somente para especular [...]. (FBV, 01/04/2009, grifo nosso).

E ainda no mesmo texto:

[...] porque bastavam a cara e a coragem ou o pistolão para se apropriar da política, das terras urbanas e rurais, dos órgãos públicos e de tudo o quanto fosse possível (e depois dizem que os índios querem tomar Roraima).... Os forasteiros foram chegando, os mais espertos viram que não precisavam pagar nada (a não ser conquistar o "compadrio" dos índios) e as terras foram sendo ocupadas por quem acreditava que tudo aquilo não tinha dono.... Até assentamentos eram incentivados porque essa gente esperta sabia que, mais cedo ou mais tarde, os colonos (de colonizados mesmo) iriam abandonar o lote. ... Como verba federal chegava a rodo para Roraima e todos (leia-se "eles") estavam felizes com essa realidade cômoda, foram empurrando tudo com a barriga [...].(FBV, 01/04/2009, grifo nosso $)$.

De acordo com Mainguenau estes recursos passam a ser peculiares a alguns autores, como vimos nos textos de Jessé Souza. Ao mesmo tempo em que utiliza as aspas para dar vozes a outras pessoas no texto, recorre aos parênteses para comentar e confirmar seu ponto de vista, o que reforça mais uma vez que, embora os textos do editor sejam plurivocais, são monológicos. Nos textos acima encontramos três momentos neste sentido. No primeiro fragmento uma explicação sobre a especulação fundiária do estado. Na sequiência, o autor ironiza o fato de muitos políticos e também parte de população dizer que o Estado, em pouco tempo seria apenas dos índios, após tantas demarcações de reservas. No final do fragmento do artigo observamos o autor explicar expressão "colonos" - de colonizados mesmo - e depois substituir a palavra "todos", por "eles" (leia-se "eles"). Tais interferências no texto, mais do que anunciar a utilização das expressões em outros artigos de sua autoria, não só indicam a posição do enunciador, seu ethos -- o de um sujeito que critica a submissão econômica e política dos colonos (reforçada pela expressão "de colonizados mesmo") -- como também reforçam sua exclusão deste grupo social e do dos arrozeiros, forasteiros e espertos, agrupados pelo pronome pessoal "eles", significando os outros, os não-roraimenses: "como verba federal chegava a rodo para Roraima e todos (leia-se "eles") estavam felizes com essa realidade cômoda, foram empurrando tudo com a barriga". 
Nos artigos seguintes o autor utiliza-se da ironia para fazer críticas à classe política, em especial à já citada visita anunciada pelo deputado federal Aldo Rebelo (PC do B-SP). A ironia algumas vezes é utilizada para fazer crítica. A frase irônica tem como característica subverter a si mesma no momento em que é proferida.

A seguir reunimos fragmentos de três artigos, em que o editor se vale do recurso da ironia para comentar a própria fala, ou seja, a frase funciona como uma contradição. Quem diz uma frase usando de ironia é porque considera tal frase um absurdo. Há duas boas pistas que indicam que uma frase é irônica: o contexto e o tom.

[...] Que a produção de arroz terá que encontrar seu novo caminho, mesmo que seja na Guiana ou no Paraguai (arroz do Paraguai. Essa é boa!). Que ficar fazendo a política do grito não dá mais.... Enquanto o governo local engana o produtor local com bugigangas e espelhos, do outro lado enche o bolso do agronegócio (os arrozeiros e sojeiros agradecem!), já que o agrobussines depende de muita grana pública a título de financiamentos e isenções.... Como as plantações são subsidiadas com dinheiro público (não existe agronegócio com investimento do próprio produtor), $\ldots$ A consequência disso pode ser vista na Expoferr: currais minguando, inexistência de produtos para mostrar (nem pepino gigante para o povo existe mais - sem trocadilho, por favor) e agricultor à míngua [...]. (FBV, dezembro de 2009, grifo nosso).

No fragmento anterior, o autor acha graça da própria frase. Os parênteses remetem à situação de os brasileiros considerem ruins ou piratas produtos exportados pelo Paraguai. Ao dizer "essa é boa", o editor deixou implícito que "só faltava mais essa" para o Estado. No segundo parênteses foi utilizada a palavra "sojeiros", pouco usual mesmo no meio de produtores, para acompanhar, rimar com arrozeiros. Depois ressalta que nem os arrozeiros plantam com recursos próprios, o que dirá os índios. Por fim o autor "pede" ao leitor que não pense em trocadilhos, mas ao fazer isso, na verdade, chama a atenção para a existência do trocadilho provocado pela polissemia da palavra "pepino", que conota o órgão sexual masculino.

Vimos nestes artigos que o editor usa uma estratégia discursiva em que finge conversar consigo mesmo. Algumas vezes volta ao recurso da ironia e se coloca na posição de leitor/receptor. Jessé Souza ainda relembra expressões utilizadas antes por ele. Com isso, dá a entender que o seu público leitor é fiel, que acompanhou os "capítulos" desta história narrada por ele. Além disso, utiliza o que Maingueneau chamou de modalização do discurso, isto é, o enunciador apoiado em outras falas (ainda que algumas sejam suas) constrói a sua própria.

${ }^{1}$ Veja-se Sirio Possenti (2011). 


\section{PROVÉRBIOS, CITAÇõeS, PALAVRAS REPETIDAS E COLOQUIAIS}

Outra característica peculiar dos textos do editor são as citações, provérbios e ditos populares. Estes recursos são utilizados para que o enunciador apóie sua fala sobre a fala de outro. Segundo Dominique Maingueneau, a enunciação proverbial é fundamentalmente polifônica, o que significa fazer com que sua voz seja ouvida, em outra voz. Para o autor a voz:

[...] da "sabedoria popular, à qual se atribui a responsabilidade pelo enunciado. $\mathrm{O}$ enunciador não explicitar a fonte desse enunciado: cabe ao enunciador explicita a fonte como tal, apoiando-se ao mesmo tempo, nas propriedade linguísticas do enunciado e em sua própria memória... (MAINGUENEAU, 2001, p. 170).

No artigo 01 publicado pelo editor, em 30 de janeiro de 2009, Jessé Souza utiliza parte de um poema de Carlos Drumond de Andrade, bastante conhecido, o que reforça mais uma vez a imagem de seu público-leitor - uma vez que não só não o destacou, como o incorporou como se fosse de sua própria autoria. Além disso, esta estratégia, conhecida como intertextualidade implícita, prevê um conhecimento já adquirido pelo leitor.

[...] Diziam também que a culpa era dos índios. Agora sabemos o que é terra dos índios e o que é terra dos "brancos". Culparam a falta de repasse das terras para Roraima; e finalmente Lula da Silva concretizou a transferência. E agora, José, que monstro vão criar? [...]. (FBV, 30/01/2009 grifo nosso).

No mesmo texto, são utilizadas expressões coloquiais que produzem efeitos de sentidos de aproximação entre leitor e enunciador. Como exemplos temos: "chutados de volta" "indios paparicados e cortejados". No artigo 02 de 11 de fevereiro, o enunciador recorre à intertextualidade explícita, citando Bertolt Brecht, dramaturgo e poeta alemão. "Pobre e podre política, como diria Bertolt Brecht", destacou. Ainda encontramos outros provérbios e ditos: "os mais espertos passam a desconfiar de cachorro amarrado com lingüiça"; "até as pedras sabem"; "gregos e troianos"; "arregaçar as mangas para trabalhar"; "estrada esta que não é asfaltada e jamais será"; "E como disse o filósofo, o rio sempre será o mesmo, mas o guia não" e "mas já disse Nelson Rodrigues: "Toda humanidade é burra". Entende-se que o provérbio é uma asserção sobre a maneira como funcionam as coisas, sobre como funciona o mundo, dizendo que é verdadeiro: 
[...] Pobre e podre política, como diria Bertolt Brecht. Não faz muito tempo, o governo petista Lula da Silva era duramente criticado. E contra ele lançada a mais dura campanha pelo fato dele ter homologado a terra indígena Raposa Serra do Sol [...]. (FBV, 11/02/2009, itálico, negrito meu).

[...] Quando os mais espertos, passavam desconfiar de cachorro amarrado com lingüiça [...]. (FBV, 01/04/2009 grifo nosso). [...] Até as pedras sabem que os Tupi-Guarani sofrem e penam por abandono governamental, mas o “comunista" de lá está preocupado com os neo-coronéis do agronegócio daqui, que insistem em não querer respeitar a Suprema Corte e esperneiam para não deixar a terra que eles ocuparam sem pagar nada, com isenção de impostos, tapete vermelho, mirra e ouro oferecidos pelo governo local. [...] $\mathrm{Se}$ a reserva yanomami e a reserva Raposa Serra do Sol fossem entregues ao agronegócio, a multinacionais do minério, a japoneses, a gregos e troianos, todos (políticos e elite econômica) estavam brindando com seus uísques e champanhes importados [...]. (FBV, 03/04/2009, itálico, negrito meu).

[...] Seja bem-vindo Lula. Sua vinda é o triunfo daqueles que sempre combateram a política do faz-de-conta. Depois que o presidente se for, todos terão que arregaçar as mangas e trabalhar. Não há mais espaço para paranóias e monstros fantásticos [...]. (FBV, 11/09/2009 grifo nosso).

[...] Muitas críticas recebi e, graças a elas, consegui enxergar o caminho do acerto, estrada esta que não é asfaltada e jamais será. Porque acertar é como construir o leito de um rio, em que é preciso desviar de serras e montanhas para seguir caminho rumo ao mar. E como disse o filósofo, o rio sempre será o mesmo, mas a água não [...] Sei que há leitores que me detestam, que me fustigam e algumas vezes me xingam ou ameaçam. Mas já disse Nelson Rodrigues: "Toda unanimidade é burra". E foi assim que comemorei a decisão do Supremo, por 10 a 1 na questão da Terra Indígena Raposa Serra do Sol, torcendo para que não fosse mesmo uma unanimidade [...](FBV, 21/10/2009, itálico, grifo nosso).

De modo geral, observa-se que os artigos do enunciador agradam o público, por falar com "tom" de liberdade o que muitos gostariam de dizer, mas não o fizeram ou fazem, por vários motivos, entre eles o receio de julgamentos. Isso foi confirmado nos comentários dos leitores enviados à redação por meio da internet, publicados no jornal impresso na coluna "Espaço do Leitor", como se vê a seguir em resposta ao artigo 01 "Eles" e o discurso, publicado no dia 30 de janeiro de 2009:

\section{[...] PARABÉNS I}

Valci Marques (valci_ceduc@yahoo.com.br) escreve para parabenizar o jornalista Jessé Souza pelo artigo intitulado 'Eles'. "Concordo em gênero e grau, estamos acompanhando aqui de João Pessoa-PB todas as notícias da nossa cidade e lendo os artigos deste jornalista e também a Parabólica. Parabéns, a toda equipe deste jornal".

\section{PARABÉNS II}

$\mathrm{Da}$ mesma forma o leitor Ademir Ferreira de Lima (limademirferreira@hotmail.com) parabeniza a todos que fazem a FBV. 
"Parabéns, por fazer o melhor jornal de nosso estado" [...].(FBV. 02/02/2009).

Tais respostas permitem afirmar que o editor conseguiu, ao longo de sua carreira, conquistar credibilidade e prestígio do jornal. Para Juvenal Zanchetta Júnior (2004, p.12), credibilidade é umas das palavras centrais para a imprensa, que permite que um veículo se consolide e seja respeitado pelo público que pretende atingir. No entanto, equacionar os fatores que explicam a credibilidade de um jornal, implica que o veículo divulgue informações consideradas confiáveis e corretas.

Para Maingueneau, na medida em que a sabedoria popular é na realidade a própria comunidade de locutores de uma língua, cada locutor é indiretamente um dos membros dessa instância. Como exemplo temos: "índios miseráveis e xucros"; ( implicitamente isso diz: sempre foram esquecidos pela sociedade, sem chances de mudar de vida) "verba federal chegava a rodo" (ou seja, havia tanto dinheiro público, que os políticos mal sabiam o que fazer ou faziam mau uso dele); "cavalo de batalha"(isto é, o carro-chefe).

Além dos ditados populares o autor por várias vezes julgou a classe política. Dos doze artigos analisados, em todos encontramos críticas, muitas vezes explicitas, porém sem dar muitos nomes. Foram utilizadas as expressões e palavras: "incompetentes"; "raça de políticos"; "caciques da polícia"; "político maluco"; "forasteiro (02 vezes)"; paranóicas/paranóicos (6 vezes); "maus políticos"; "zoológico humano"; "outros mais espertos"; "defensor de Roraima, "loucos e lesa pátria”, "grito patético", "o pai da criança", "falsos nacionalistas", “Ah! Lá no gabinete”, "Rambo de Roraima”, "monstros (04 vezes)" "defensor de Roraima", "espertalhões" (03 vezes), dentre outros.

Embasada pelo pensamento de Bakhtin entendemos que os diferentes aspectos da enunciação podem ser sutilmente postos em evidência. O narrador, nestes artigos o editor, pode "apagar as fronteiras do discurso citado, a fim de colori-lo com as suas entoações, seu humor, ironia, ódio, encantamento ou desprezo". Na verdade entendemos que estes recursos foram utilizados para prender a atenção do leitor. Com uma linguagem mais simples e até dura, o editor transmite o seu sentimento e o de muitos outros a respeito da classe política.

\subsection{Títulos: o que existe entre as palavras?}

Apresentamos neste tópico a análise dos títulos dos artigos. Deixamos este item para o final, uma vez que as respectivas matérias já foram analisadas. 


\begin{tabular}{|c|c|c|}
\hline 1 & $30 / 01 / 2009$ & "Eles" e o fim do discurso \\
\hline 2 & $11 / 02 / 2009$ & Sapo barbudo vira príncipe \\
\hline 3 & $01 / 04 / 2009$ & "Terra de Ninguém" \\
\hline 4 & $02 / 04 / 2009$ & Fim de um ciclo \\
\hline 5 & $03 / 04 / 2009$ & Cai mais um entulho \\
\hline 6 & $01 / 05 / 2009$ & Mais que espernear \\
\hline 7 & $05 / 05 / 2009$ & Hora de trabalhar \\
\hline 8 & $15 / 09 / 2009$ & Pluralidade nos 26 anos \\
\hline 9 & $21 / 10 / 2009$ & Vale-Preguiça e Pró-moleza \\
\hline 10 & $09 / 12 / 2009$ & Nem pepino para o povo \\
\hline 11 & $08 / 12 / 2009$ & A faca e o queijo \\
\hline 12 & $17 / 12 / 2009$ & \\
\hline & & \\
\hline
\end{tabular}

Quadro1 - Títulos dos artigos publicados na FBV por Jessé Souza

Fonte: Construído pela autora (2011)

A titulação é um recurso jornalístico, que mais do que contribuir com a parte gráfica, antecipa informações e chama a atenção, com elementos narrativos como se falasse diretamente com o leitor (ZANCHETTA, 2004, p.45). Além disso, de maneira geral não são diretos. Para saber de qual assunto se trata seria necessário iniciar a leitura, trazendo assim o leitor para dentro do texto, função principal do título. Neste item, a intenção foi revelar a racionalidade do campo jornalístico enquanto lugar enunciador. Quando pegamos um pedaço de papel com algo escrito, o primeiro que se procura ler é o título. Isto porque a primeira impressão que se recebe da notícia vem do título.

Para Abreu o texto, o entretítulo, a foto, a localização da matéria na página, as chamadas e a escolha da própria página compõem o chamado discurso jornalístico. Se examinados isoladamente, oferecem uma visão fragmentada do contexto. Estes fragmentos são reveladores quando assumem um caráter emblemático, sendo a palavra o menor fragmento do discurso jornalístico e muitas vezes o mais revelador. As palavras, segundo o autor ganham peso, seu lugar social, de acordo com o uso e apropriação que os sujeitos fazem dela. E muitas vezes podem conduzir a formulação de um conceito enraizado na ideologia do repórter. (ABREU, 2000, p.151). 
Segundo Keske (2001, p.148), os títulos expressam a informação mais importante, mais pertinente ou mais surpreendente do relato da notícia. Entre outros fatores, o título serve para persuadir o leitor. Se o título interessa, o leitor continua com o texto.

Entendemos que os títulos fazem ver e esconder o texto, como um véu transparente, que mostra o que esconde, aquilo que se dá a ver, que dão forma e conteúdo àquilo que se refere. Neste sentido, a eleição de palavras específicas podem assinalar a inserção de quem o produz. Em jornais apelativos são pronunciadas as funções emotiva (o texto expõe um posicionamento ou sentimento determinado revela sua opinião, sua emoção. Nela prevalecem, interjeições e exclamações) e apelativa (o texto aponta e induz o leitor a um posicionamento) (ZANCHETTA, 2004).

Apesar de não acreditar que o jornal possa ser considerado apelativo, observamos nos títulos do editor -chefe jornal FBV, funções emotivas e apelativas. A maioria dos títulos possui caráter emotivo. Observe os títulos: "Sapo Barbudo vira príncipe”, "Solidariedade?!”, “Cai mais um entulho”, "Mais que espernear”, "Vale-Preguiça e Prómoleza" e "Nem pepino para o povo". Nestes o editor se posiciona acerca do assunto tratado no corpo do texto.

Em "Sapo Barbudo vira príncipe”, por exemplo, a construção de palavras produz o efeito de sentido de que o "feitiço" que mantinha o príncipe no corpo de um sapo, foi desfeito. O "beijo" que teria conseguido essa "façanha" foi o repasse de terras endossado pelo presidente Luiz Inácio Lula da Silva. Nos títulos seguintes, a função emotiva volta a aparecer. Em "Solidariedade!?” implicitamente os sinais de pontuação perguntam e afirmam "para quê". Em "Cai mais um entulho”, demonstra o posicionamento do editor quanto à votação do STF que decidiu pela não obrigatoriedade do diploma de jornalismo, para exercer a profissão. Além disso, ele adjetiva o diploma de jornalismo: um entulho. Apenas no corpo do texto, Jessé Souza considera a posição do STF tão retrógrada quanto a decisão referente à T.I Raposa Serra do Sol. O mesmo efeito aconteceu em "Vale-Preguiça e Pró-moleza”. Na seqüência, os títulos "Mais que espernear", e "Nem pepino para o povo", retratam o sentimento sobre a desintrusão e a Exposição Agropecuária do Estado.

Os outros quatro títulos do editor apresentaram a função apelativa, que chama, induz o leitor ao posicionamento expresso no texto, isto é o enunciador procura influenciar o comportamento do receptor. Observe: "Terra de Ninguém", "Fim de um ciclo", "Hora de trabalhar" e "Pluralidade nos 26 anos". Os títulos são sugestivos, ou seja, sugerem que o 
leitor concorde, tenha o mesmo posicionamento. Em "Terra de Ninguém”, o editor induz o leitor a pensar o mesmo que ele, como se o Estado, realmente não tivesse dono, ou leis. $\mathrm{Na}$ seqüência em "Fim de um ciclo" o editor destaca que a partir daquele momento, o "ciclo", ou seja, a busca dos índios pela terra teria acabado, sugerindo, porém, que poderão vir novos ciclos. No título "Hora de Trabalhar", o editor convida o leitor a fazer isso. Afinal o processo de desintrusão acabou, não há mais sentido reclamar e sim começar a trabalhar. No último título, "Pluralidade nos 26 anos", Jessé Souza também reproduz o seu posicionamento. Desta vez sobre a linha editorial do jornal para o qual trabalha, definindo - a como plural, que abrange várias vozes.

A partir da observação dos títulos que compõem o corpus deste trabalho, percebemos que o editor tratou o assunto por meio de diferentes formas. Ou seja, contestou, determinou ações e ainda opinou sobre determinados temas. Em linhas gerais percebeu-se que por trás das palavras que compuseram títulos e corpo dos artigos, existiu uma construção orquestrada de idéias, que muitas vezes passam despercebidas pelos leitores/consumidores diários de jornais.

Além disso, ficou claro, por meio dos artigos, que a posição tomada pelo editor, que saiu em defesa dos índios, confirmou a hipótese inicial em dois aspectos: um deles está ligado ao fato de ser descendente de índio e ter visto de perto, por várias vezes, a luta pela terra. $\mathrm{O}$ outro está na base da construção do pensamento crítico do editor. Ainda jovem começou a trabalhar na Diocese do Estado. A instituição católica sempre foi uma das defensoras dos interesses dos indígenas. Esta mesma instituição foi acusada pelos arrozeiros de defender os índios para adquirir terras.

Vale ressaltar, entretanto, que apesar de o editor apoiar a demarcação da reserva em terras contínuas, boa parte da população do Estado foi contrária a essa opinião. Ele mesmo cita isso em um de seus artigos:

Embora eu tenha 13 anos de carteira assinada na Folha, comecei a escrever neste espaço antes, completando os 14 anos de casa. Não lembro exatamente a data - e também não tenho interesse em pesquisar - de quando foi o primeiro artigo. Mas lembro-me do tema: questão indígena. [...]A página de Opinião da Folha construiu uma história à parte dentro do jornal. Porque aqui desfilou o pensamento de leitores, de especialistas, de cronistas, partidários, apaixonados, nem tão apaixonados assim e gente de diversas nuances de pensamento. [...]Sei que há leitores que me detestam, que me fustigam e algumas vezes me xingam ou ameaçam. Mas já disse Nelson Rodrigues: "Toda unanimidade é burra". E foi assim que comemorei a decisão do Supremo, por 10 a 1 na questão da Terra Indígena Raposa Serra do Sol, torcendo para que não fosse mesmo uma unanimidade. Os 
26 anos da Folha quero festejar, também, com os leitores da página de Opinião. São vocês, leitores e escritores de artigo, que contribuem para a pluralidade deste jornal. Esse é o maior presente que vocês deram à Folha ao longo dessas duas décadas e meia de história [...]. (FBV, 21/10/2009, grifo nosso).

Nos trechos acima, quando Jessé Souza diz que há leitores que o detestam, reconhece que o fato de "defender" os índios não é o pensamento de todos do Estado. Porém, ao constatar isso, Jessé Souza não se chateia e sim comemora o fato de nem todos pensarem de forma igual, situação que, para ele, seria sinônimo de burrice. As opiniões contrárias são o que favorecem a pluralidade de ideias e fortalecimento do jornal.

\section{CONSIDERAÇÕES}

A análise do discurso dos artigos do editor Jessé Souza nos permitiu observar que um dos temas inspiradores para ele é a questão indígena. Para o enunciador, falar sobre o assunto é tentar de alguma forma fugir de imposições dos governantes. Ficou evidente, também, em alguns enunciados, que o editor não fez questão de esconder as características do seu ethos, apesar de não ter ser autodeclarado como indígena.

Analisando os textos e considerando o contexto parte tão importante quanto o próprio texto escrito, entendemos que o discurso de alguém toma forma diferente de acordo com o lugar, espaço e momento em que é dito. Desta maneira, Jessé Souza, ao viver a de desintrusão, não teria condições de afastar-se completamente das relações sociais que o cercavam. Mais ainda: como ele se utilizou várias vezes da própria fala/texto para relembrar os fatos, apesar da presença de outras vozes em seus artigos, acabou prevalecendo a do jornal. Afinal, trata-se do editor da FBV, cargo ligado ao poder e, portanto, configurando uma voz hegemônica ao seu final, que se sobrepôs às demais.

\section{REFERÊNCIAS}

ABREU, J. B. As manobras da informação: análise da cobertura política armada no Brasil (1975-1979). Niterói: Mauad, 2000. 292 p.

BAKTHIM, M. Marxismo e filosofia da Linguagem: problemas fundamentais da linguagem. São Paulo: Hucitec, 2009. 208 p. 
BRAIT, B. O texto mostra a língua, costura e descostura discursos. Filologia e linguiística portuguesa. São Paulo, n. 9, p. 169-183, 1997.

Bakhtin: Conceitos chaves. São Paulo: Contexto, 2010. 224 p.

GREGOLIM, M. do R. Análise do discurso e mídia: a (re)produção de identidades comunicação, mídia e consumo. Comunicação, Mídia e Consumo/ESPM, São Paulo, v. 4, n. 11, p.11-25, 2007

KESKE, H. I. Título oculto derruba ministro da justiça: Zero Hora versus Correio do Povo na persuasão do leitor de cada dia. Revista Famecos, Porto Alegre, n. 16, p.148-161, dez. 2001. Quadrimestral.

MAINGUENEAU, D. Análise de Textos de Comunicação. São Paulo: Cortez, 2001. 238 p.

MELO, J. M. de. Jornalismo opinativo: Gêneros opinativos no jornalismo brasileiro. $3^{\text {a }}$ ed. Revista e Ampliada. Campos do Jordão: Mantiqueira, 2003. 239 p.

POSSENTI, S. Procurando o outro: Citações. Frases Célebres. Disponível em:

$<$ http://www.iel.unicamp.br/projetos/conexaolinguagem/files/atividades/AtividadeCitacoes.pd f>. Acesso em: 23 mar. 2011.

SANTILLI, P. Pemongon Patá: território Macuxi, rotas de conflito. São Paulo: UNESP, 2001.

SOUZA, Jessé . Pedidos Roraima. Entrevista concedida a Wenya Alecrim via e-mail. 03 abr. 2010.

, Jessé. A faca e o queijo. Folha de Boa Vista. Boa Vista. 17 dez. 2009. Opinião. p. 2.

, Jessé. Cai mais um entulho. Folha de Boa Vista. Boa Vista. 01 mai. 2009. Opinião. p. 2.

, Jessé. Eles e o fim do discurso. Folha de Boa Vista. Boa Vista 30 jan. 2009. Opinião. p.2.

_, Jessé. Fim de um ciclo. Folha de Boa Vista. . Boa Vista. 02 abr. 2009. Opinião. p.2.

, Jessé. Hora de trabalhar. Folha de Boa Vista. Boa Vista. 15 set. 2009. Opinião. p.2. 
, Jessé. Mais que espernear. Folha de Boa Vista. Boa Vista. 05 mai. 2009. Opinião. p.2.

, Jessé. Nem pepino para o povo. Folha de Boa Vista. Boa Vista. 08 dez. 2009. Opinião. p.2.

, Jessé. Pluralidade nos 26 anos. Folha de Boa Vista. Boa Vista. 21 out. 2009. Opinião. p.2.

, Jessé. Sapo barbudo vira príncipe. Folha de Boa Vista. Boa Vista 11 fev. 2009. Opinião. p.2.

, Jessé. Solidariedade?! Folha de Boa Vista. Boa Vista. 03 abr. 2009. Opinião. p.2.

, Jessé. “Terra de Ninguém”. Folha de Boa Vista. Boa Vista. 01 abr. 2009. Opinião.

p.2.

, Jessé. Vale-Preguiça e Pró-moleza. Folha de Boa Vista. Boa Vista. 09 dez. 2009.

Opinião. p.2.

ZANCHETTA, J. Imprensa escrita e telejornal. São Paulo: UNESP, 2004. 134 p.

Original recebido em: 11/05/2011

Aceito para publicação em: 12/09/11

Resumo sobre os autores:

${ }^{1}$ Wenya Alecrim é mestranda em Comunicação, pela Universidade Paulista (UNIP), especialista em Telejornalismo pela Universidade Estácio de Sá, possui graduação em jornalismo (2004), pela mesma universidade. Trabalha como repórter do Canal Rural e é docente na Faculdade Objetivo- IESRVER. Já trabalhou no jornal Folha de Boa Vista, TV Roraima, entre outras TVs filiadas Globo. Além disso, atuou como assessora de comunicação em diversas instituições públicas e privadas.

http://buscatextual.cnpq.br/buscatextual/visualizacv.do?id=K4294740H0

${ }^{2}$ Barbara Heller possui graduação em Teoria Literária pela Universidade Estadual de Campinas (1982), mestrado em Ciências da Comunicação pela Universidade de São Paulo (1990) e doutorado em Teoria Literária pela Universidade Estadual de Campinas (1997). Atualmente é docente do Mestrado em Comunicação da Universidade Paulista (Unip), parecerista ad hoc da Fapesp e pesquisadora associada do projeto temático A cena paulista -- um estudo da produção cultural de São Paulo a partir do acervo Miroel Silveira, na ECA - Usp. É membro do Núcleo de Pesquisa em Comunicação e Censura da ECA-Usp e também é pesquisadora do grupo de pesquisa Mídia, Cultura e Política: identidades, representações e configurações do público e do privado no discurso midiático -- Unip.

http://buscatextual.cnpq.br/buscatextual/visualizacv.do?id=K4785752U8 